The research program of the Center for Economic Studies (CES) produces a wide range of theoretical and empirical economic analyses that serve to improve the statistical programs of the U.S. Bureau of the Census. Many of these analyses take the form of CES research papers. The papers are intended to make the results of CES research available to economists and other interested parties in order to encourage discussion and obtain suggestions for revision before publication. The papers are unofficial and have not undergone the review accorded official Census Bureau publications. The opinions and conclusions expressed in the papers are those of the authors and do not necessarily represent those of the U.S. Bureau of the Census. Republication in whole or part must be cleared with the authors.

\title{
Immigrant Status, Race, and Institutional Choice in Higher Education
}

\author{
By \\ J. Farley Ordovensky \\ Department of Economics \\ University of the Pacific \\ Stockton, CA 91711 \\ jfarley@vms1.cc.uop.edu \\ and \\ Alison P. Hagy \\ Center for Economic Studies \\ U.S. Bureau of the Census \\ Washington, DC 20233 \\ ahagy@ces.census.gov \\ CES 98-4 March 1998
}

All papers are screened to ensure that they do not disclose confidential information. Persons who wish to obtain a copy of the paper, submit comments about the paper, or obtain general information about the series should contact Sang V. Nguyen, Editor, Discussion Papers, Center for Economic Studies, 
Washington Plaza II, Room 211, Bureau of the Census, Washington, DC 20233-6101, (301-457-1882) or INTERNET address

snguyen@info.census.gov .

\section{Abstract}

This paper examines the postsecondary enrollment decisions of immigrant students, expanding on previous work by explicitly considering their choices among institution types and by examining differences across generations and racial/ethnic categories. Using data from the National Educational Longitudinal Study (NELS:88), we hypothesize that community colleges may play a more significant role in providing access to higher education for immigrants than for the native-born population. Our results support our hypothesis only among Asian immigrants. First-generation black immigrants have a higher probability of enrolling in private vocational schools, while second-generation Hispanics (and native blacks) have a higher probability of enrolling in both public and private four-year colleges and universities.

Keywords: Higher education, immigration, National Educational Longitudinal Survey (1988)

Earlier drafts of this paper were presented at the 1996 Southern Economic Association Annual Meetings; the 1997 Western Economic Association Annual Meetings; and in the Economics Department Colloquium at the University of the Pacific. Helpful comments from seminar participants, Cecelia Conrad and Ron Jarmin are 
gratefully acknowledged. Financial support was provided by the John Randolph and Dora Haynes Foundation. The authors absolve the funding agency and colleagues from responsibility for the contents of this paper. 


\section{Introduction}

In the 1980's, more than one-third of the population growth in the United States was the result of immigration, and the U.S. Census Bureau projects a record number of immigrants (between nine and twelve million) will enter the U.S. in the 1990's (Stewart 1993, 1). Since immigrants represent an increasingly significant fraction of the workforce, future productivity in the economy will depend, in part, on how well prepared the immigrant population is to fill the needs of the labor market. This, in turn, depends to a large extent on how well our nations schools succeed in educating and training immigrant youth.

Much research in the last two decades has focused on the education of immigrant children in primary and secondary schools (Duran and Weffer, 1992; McDonnell and Hill, 1993; Kao and Tienda, 1995). In addition, numerous studies have examined the labor market outcomes and economic attainment of the immigrant population (Stewart and Hyclak, 1984; Borjas, 1985; Borjas and Tienda, 1989; Funkhauser and Trejo, 1995; Schoeni, McCarthy and Vernez, 1996). However, surprisingly little research has addressed the intermediate issues of immigrant youth 7 access to

and attainment in postsecondary education. As the demands of the labor market increasingly require skill and training beyond that acquired in high school, access to and participation in higher education is vital if immigrant youth are to become fullyintegrated, productive contributors to the domestic economy. 
This paper helps fill that gap in the literature by addressing how, if at all, postsecondary enrollment patterns differ between immigrant and native students. Many studies have addressed the factors affecting individuals=choices among postsecondary enrollment alternatives. These previous works have ranged from a general and comprehensive analysis of the enrollment decision (e.g. Radner and Miller 1975; Manski and Wise, 1983) to a specific focus on choice among institution types (e.g. Ordovensky 1995; Rouse, 1994) to focus on the behavior of specific ethnic groups (e.g. Astin 1982; Ganderton and Santos, 1995). However, little explicit attention has been paid in these studies to the effect of immigrant status on postsecondary enrollment behavior.

In a recent Rand report on immigrants in U.S. education, Vernez and Abrahamse (1996) provide the first thorough empirical investigation of the college choice behavior of immigrant youth that controls for variations in individual and family characteristics. Using data from the national longitudinal survey, High School and Beyond, they examine postsecondary enrollment and attainment behavior of immigrants in the 1980 high school senior class compared to that of native-born students in the same cohort. Their results suggest that immigration status per se does not significantly affect the probability of college attendance. 
Our research expands on the work of Vernez and Abrahamse in several ways. First, we use data from the National Educational Longitudinal Study (NELS:88) that provides information on postsecondary enrollment and other activities in the first two years after high school for the graduating class of 1992 . As the 1980's saw high levels of immigration, and significant changes from historical patterns of countries of origin, one might expect significantly different behavior in the 1992 high school senior cohort compared to that observed in the class of 1980. The NELS:88 data provide the first opportunity to examine the posthigh school experiences of the 1992 high school senior cohort. Furthermore, the data are particularly well-suited for this study as the survey purposely oversampled Asians and Hispanics, the two groups that represent the great majority of the recent immigrant population.

Second, our model is explicitly designed to examine not just the dichotomous choice of whether or not to enroll, but rather the choice from among the variety of available postsecondary enrollment options. This specification of the model allows the probability of alternative enrollment options to be affected in different ways by immigrant status. Thus, effects that may be masked when enrollment in all institution types is aggregated into one choice may be exposed with this more detailed definition of the choice variable. 
More specifically, we hypothesize that community colleges may play a more significant role in providing access to higher education for immigrants than for the native-born population. These two-year schools are typically more responsive and flexible in their scheduling and course offerings and are in many ways more user-friendly for students who have little experience with the U.S. higher education system than are traditional four-year colleges and universities, particularly the private institutions. Also community colleges offer vocational training programs that might provide more attractive enrollment options for students who want further education but are unsure of their ability (perhaps due to limited English proficiency or simply because of unfamiliarity with the system) to succeed in traditional academic fields. In the presence of this latter effect, we would also expect to see more enrollment of immigrants in private vocational and trade schools.

Finally, we explore how enrollment choices may differ between first- and second- generation immigrants and across ethnic subgroups. While Vernez and Abrahamse explore differences across ethnic subgroups in their analysis, they do not distinguish between first- and second-generation status. Previous research offers conflicting evidence on how educational achievement differs between first and second generation immigrants. For example, Rumbaut (1995) finds educational 
achievement declines from the first to the second generation, while Kao and Tienda (1995) conclude that second-generation youth are best positioned to achieve scholastically. This paper

further investigates the question of postsecondary enrollment behavioral differences across generations in order to increase our understanding of the process of assimilation.

\section{Model}

In our model, the individual has a choice from among five postsecondary enrollment alternatives: four-year public college or university, four-year private college or university, public less-than-four-year schools (overwhelmingly two-year community/junior colleges), private less-than-four-year institutions (mostly proprietary vocational/technical schools), or non-enrollment. The student is assumed to select from among the available options that which yields the highest utility for him. The utility derived by individual i from the choice of alternative $j$ is defined as

$$
U_{i j}=\beta_{j} X_{i}+\varepsilon_{i j}
$$

where $X_{i}$ is a vector of characteristics specific to the ith individual and $\beta_{j}$ is a vector of coefficients for the jth alternative. These individual-specific explanatory variables include characteristics of the individual students, their families and secondary schools, and their postsecondary alternatives. 
The generalized multinomial logit model is used to estimate the probability of each of the alternatives being chosen. ${ }^{1}$ That is, for each value of the choice variable, the model estimates the probability of that option generating the highest utility for that individual. The predicted probability that an individual with the characteristics $X_{i}$ will select alternative $j$ from among the $m$ alternatives is defined as

$$
P_{i j}=\frac{e^{\beta_{j^{\prime} X_{i}}}}{\sum_{k=1}^{m} e^{\beta_{k^{\prime}} X_{i}}} .
$$

In a model with $n$ individual characteristic variables and $m$ values for the choice variable, estimation of the model yields $(n-1){ }^{*} m$ parameter estimates. For identification, the vector of coefficients for one of the values of the choice variable must be standardized to zero. Thus, the coefficient $\beta_{n j}$ represents the predicted effect of a change in the nth independent variable on the probability of choosing alternative $j$ relative to the probability of choosing the normalized alternative. Specifically, the estimated coefficient yields the log-odds ratio,

$$
\log \frac{P_{i j}}{P_{i m}}=X_{i}\left(\beta_{j}-\beta_{m}\right)
$$

\footnotetext{
${ }^{1}$ See Maddala (1983) for a detailed description of the multinomial logit model.
} 
where $\beta_{\mathrm{m}}$ is standardized to zero.

In our model, the natural choice for the normalized

alternative is the choice of non-enrollment. Thus, the estimated coefficients represent the effect of a change in the independent variable on the log of the probability of choosing one of the four enrollment options relative to the probability of choosing non-enrollment. To calculate the direct (rather than relative) effect of each independent variable on the probability of choosing a given alternative, one must evaluate the partial derivative of the probability function (equation 2) with respect to the variable of interest, which can be shown to be

$$
\frac{\partial P_{j}}{\partial X_{n}}=P_{j}\left(1-P_{j}\right) \beta_{X_{n} j}-P_{j} \sum_{k \neq j} P_{k} \beta_{X_{n} k},
$$

where $\beta_{X_{n} j}$ and $\beta_{X_{n} k}$ are the estimated coefficients for the ith explanatory variable, $X_{i}$, for alternatives $j$ and $k$, respectively. These partial derivatives represent percentage point changes in enrollment probability associated with a change in the explanatory variable. For categorical variables that take the value of either zero or one, the partial derivative provides only an approximate value of the direct effect. The effect of a change in one of these variables is more appropriately measured by comparing the predicted probabilities when the variable equals one versus when it equals zero (Liao, 1994). In this study, both 
methods yield essentially equivalent results; the reported results are generated with the simulated probability method.

\section{Data}

We use data from the National Educational Longitudinal study (NELS:88) which conducted a survey of a representative sample of students nationwide who were enrolled in the 8th grade in 1988 . In addition to surveying and testing the students, NELS:88 also administered questionnaires to the student's school administrator, two of the student's teachers, and one of the student's parents. These supplemental questionnaires provide additional information on family and school characteristics that may significantly affect the student's enrollment decision. Follow-up surveys have been conducted at two-year intervals and data are now available through the third (1994) follow-up. Thus, for the first time it is possible to examine the initial postsecondary enrollment decisions of this group of students.

The sample of respondents used for our study are those who participated in the base year and all follow-up surveys. Participation by a student in each wave of the survey was necessary for us to obtain adequate information regarding the students' immigration status, high school preparation, and postsecondary enrollment activity. Among the 13,120 students who participated in each wave of the survey, we omitted from analysis those with missing responses on relevant variables, which left a 
sample of 10,465 students for our estimation. These data are weighted to represent the national cohort of students who would have been in 8 th grade in $1988 .{ }^{2}$

The dependent variable is the first type of postsecondary institution in which the student enrolled following his or her senior year of high school. In accordance with previous studies of enrollment choice (Manski and Wise, 1983; Ordovensky, 1995), the dependent variable is defined as the first institution in which the student was enrolled in October following high school graduation (October 1992 for our sample). If the student was not enrolled in October, the institutional choice is defined as the first institution in which the student enrolled prior to July 1993. Thus, our definition represents the first enrollment choice in the year following the cohorts senior year of high school. We chose this broad definition of first institutional choice to allow for nontraditional enrollment patterns that may be more prevalent among the immigrant population. Currently, our data only allow us to examine the initial choice of postsecondary institution; however, as data become available we plan to examine not only first institutional choice but also patterns of enrollment, such as transfer from two-year to four-year colleges.

\footnotetext{
${ }^{2}$ See U.S. Department of Education (1996) for details on the calculation of these weights.
} 
The independent variables include characteristics of the individual students, their families and secondary schools, and their postsecondary alternatives. Brief descriptions and means of these variables are presented in Appendix A. Characteristics of the individual students include sex, race/ethnicity, immigrant status, and a series of variables proxying for ability. Students are classified as first-generation immigrants if they were foreign-born and at least one of their parents were foreignborn. ${ }^{3}$ If the student was native-born but at least one of his or her parents were foreign-born, then the student is considered a second-generation immigrant. All other students are classified as members of the native-born population.

\footnotetext{
${ }^{3}$ We require at least one of the students parents be foreign-born to avoid classifying foreign-born students of native-born parents (e.g. military families stationed abroad) as immigrants.
} 
Explanatory variables designed to control for the effects of the students=family backgrounds include income, number of siblings, and a series of variables describing parents $=$ educational attainment and occupational status. Number of siblings in the student $;$ family is intened to more fully capture a familys ability to pay for their childs college education. ${ }^{4}$ Measures of parents=educational attainment and occupational status are included to control for the direct effect these measures of parental achievement may have on their childrens educational choices apart from the impact felt through their effect on family income.

Characteristics of the students=secondary schools include a dummy variable indicating attendance at a private secondary school and a series of variables proxying for peer group effects. Ganderton and Santos (1995) find that attending a Catholic high school exerts a positive influence on the probability of attending college for Hispanic high school graduates. We include all private schools (40\% of which are Catholic) in our definition of private school attendance and expect to find a similar effect. In addition, we include a set of dummy variables indicating that either a high or low percentage of the student 7 high school class is enrolled in college-preparatory courses. Previous

4 In particular, Becker (1981) proposes an inverse relationship between family size and a familys investment in each childs education. 
studies have found that the percentage of a students class that attends college has a significant effect on the probability that the student will choose to attend college himself (Fuller, Manski, and Wise, 1982; Ordovensky, 1995).

The students=access to postsecondary education is captured with a series of dummy variables indicating the region in which the student $\mathrm{high}$ school is located. These variables are our best measure of institutional access and are expected to capture broad regional variations in the provision of postsecondary education. For example, if a student graduates from high school in the Northeast, there are more private colleges and universities available in his or her region than are available to students in other parts of the country. Alternatively, students in the West have access to a much more highly-developed public two-year college system than do those in the East or south. While these regional variables are obviously too broad to test hypotheses regarding institution-specific access, they do serve to capture general patterns of institutional availability . Including characteristics of the individual students, their families and their schools as explanatory variables in the model allows us to control for the effects of these variables on the enrollment behavior of students; thus, we can isolate any specific Aimmigrant effect@on enrollment probabilities. For example, the simple enrollment frequency data in Table 1 
indicates that within the immigrant population, Hispanic nonenrollment frequencies are dramatically higher than those of other subgroups. This result may be attributable to a variety of characteristics, including (but not limited to) the fact that this group is more likely than their native counterparts to have three or more siblings (58\% of first-generation Hispanics versus 49\% of native Hispanics) or to have a father with less than a high school education (46\% versus 36\%, respectively). Using multivariate analysis allows us to determine, not only how these demographic variables affect enrollment probabilities, but also whether there is a separate, distinct effect of immigrant status, holding all else constant.

\section{Results}

Coefficient estimates from the multinomial logit models are presented in Tables 2 and 4 . These values represent the effect of an independent variable on the probability of choosing each of the enrollment alternatives relative to the probability of choosing non-enrollment. Tables 3 and 5 provide estimates of the direct effect of an independent variable on the probability of choosing each of the postsecondary options, including nonenrollment. ${ }^{5}$

\footnotetext{
5 See discussion of equation (4) in the description of the model.
} 
For illustrative purposes, consider the math score quintile variable. The coefficient estimates in Table 2 indicate that scoring in a higher quintile increases the probability of choosing each of the enrollment alternatives relative to the probability of choosing non-enrollment. However, looking at Table 3, we see that an increase in math score quintile actually decreases the probability of enrolling in private and public less-than-four-year institutions (by 0.6 and 1.5 percentage points, respectively), although not nearly as much as it decreases the probability of non-enrollment (17 percentage points). These lower enrollment probabilities are compensated by higher enrollment probabilities in private and public four-year colleges and universities (by 6.4 and 12.6 percentage points, respectively). Thus, for each of the independent variables, the change in enrollment probabilities will necessarily sum to zero. Of greatest interest in the first estimation (Table 2) are the two variables indicating immigrant status. The results indicate that first-generation immigrants are significantly more likely to choose each of the enrollment alternatives, except the option of a private four-year college or university, relative to non-enrollment. Controlling for all other individual, family, and school characteristics, first-generation immigrants are 8.1 percentage points less likely than native-born students to choose non-enrollment in their first year after high school. Most of 
the higher enrollment probability in this group occurs at the public institutions, both community colleges and four-year colleges and universities (a total of 5.6 percentage points). However, there is also a 3.2 percentage point increase in the probability of choosing a private vocational school.

Not only is first-generation immigrant status significant, it is of remarkable magnitude relative to the effects of many of the control variables. Apart from math score quintile (an increase in which decreases the likelihood of non-enrollment by 17 percentage points), first-generation status has the largest effect on non-enrollment. Parental education effects, with magnitudes in the 3 to 5 percentage point range, have the next greatest impact. Thus, not only does immigrant status matter, it appears to matter much more than many other variables commonly understood to explain enrollment choice.

In contrast to the first-generation immigrant effect, second-generation enrollment patterns are not as markedly different from those of native-born students. Most notably, second-generation immigrants are only 3.7 percentage points less likely than native-born students to choose not to enroll in their first year after high school. While a variety of explanations could be offered to explain this result, the simplest would be that with assimilation the Aimmigrant effect@is dampened. The only institutional alternative that sees a continued immigrant 
effect into the second generation is the community college option. Specifically, the probability of initial enrollment in a public two-year colleges is 2.4 percentage points higher for second-generation than for native-born students. The strength of this effect may be attributable to the ability of these institutions to be more responsive to the specific needs of the local immigrant community. Additionally, in many areas public two-year colleges may provide students with the only postsecondary option that allows them to live at home. To the extent that proximity is more important for students of nonnative parents, the desire to live at home could help explain the continued second-generation effect.

The existence of these significant immigrant effects immediately raises the question of whether these effects hold across all immigrant groups or whether they vary across immigrant groups of different race/ethnicity. In the second multinomial logit estimation (Table 4), we interact first- and secondgeneration immigrant status with the series of variables indicating race/ethnicity. Since the estimation still includes categorical variables for race/ethnicity, the coefficient estimate on first-generation Asian, for example, should be interpreted as the additional effect of being a first-generation Asian immigrant. Thus, the total effect of being a first- 
generation Asian immigrant would be the sum of the coefficient on Asian/Pacific Islander and the coefficient on first-generation Asian. In contrast, the effect of being a native Asian would simply be the coefficient on Asian/Pacific Islander.

Among first-generation immigrants, Asians and Hispanics are significantly more likely to enroll in public two-year institutions (and, for Asians, public four-year schools as well) relative to the choice of non-enrollment. While the magnitude of this effect is fairly small for Hispanics, first-generation Asian immigrants have an increase in enrollment probability, relative to their native counterparts, of 5.3 percentage points at community colleges and 2.1 percentage points at four-year public institutions. These results suggest that, particularly for first-generation Asians, public colleges (particularly community colleges) play an important access role to postsecondary education. In contrast, the coefficient for first-generation black immigrants is only significant for the probability of enrolling in private less-than-four-year colleges. The magnitude of this effect is remarkably large--first generation blacks are 11.5 percentage points more likely than native-born blacks to choose this enrollment alternative.

In the second generation, Asians are again more likely to enroll in public two-year colleges, and the size of this effect increases from the first to the second generation (from 5.3 to 
7.2 percentage points). Community colleges appear to play an increasingly important role in the postsecondary education of successive generations in the Asian immigrant population. However, the positive effect of Asian immigrant status on public four-year enrollments seen in the first generation disappears. For second-generation Hispanic immigrants, enrollment patterns are even more unlike their native counterparts than were those of the first-generation. Second generation Hispaniscs have a greater probaility of choosing every enrollment option, except less-than-four-year private institutions, relative to nonenrollment. While second-generation Hispanic immigrants have a slightly greated likelihod of non-enrollment than do firstgeneration Hispanics, the former group is, at the same time, much more likely to enroll in traditional four-year colleges and universities. Specifically, second-generation Hispanic immigrants are 4.6 percentage points more likely than native whites to enroll in a four-year college or university (an increased probability of 2.3 percentage points each at private and public institutions).

These results on Hispanic immigrant enrollment probabilities are somewhat surprising in light of recent research by Vernez and Abrahamse (1996) suggesting a decline in the educational expectations of immigrant Hispanic youth from one generation to the next. No other immigrant group exhibits this effect; among 
natives, a similar effect is found only for blacks. That is, native blacks have a greater probability than native whites of enrolling in both private and public four-year institutions (5.2 percentage points higher for private schools and 3.7 for public.)

This large, significant four-year college enrollment effect among native blacks has been found fairly consistently in other enrollment studies (Venti and Wise, 1983; Ordovensky, 1995). Several explanations have been suggested for this result, including the prevalence of four-year (both public and private) historically black institutions and successful affirmative action efforts (which are much more pronounced at four-year institutions) .

A similar explanation could be offered for the tendency of second-generation Hispanics to attend four-year institutions. Within the Hispanic population, second-generation immigrants may be best poised to attend traditional four-year colleges or universities, having assimilated sufficiently to have gained a knowledge of the system, yet still benefitting from the heightened educational expectations of their immigrant parents. ${ }^{6}$ Second-generation Hispanic immigrants (in contrast to their

\footnotetext{
${ }^{6}$ See Kao and Tienda (1995) for a similar explanation for the educational success of this group of immigrants.
} 
Asian counterparts) may be benefitting from affirmative action efforts more focused on blacks and Hispanics.

Among the control variables used in both estimations, the coefficients conform to a priori expectations and the results of other studies of postsecondary enrollment choice. For example, higher income and ability (particularly as measured by math score quintile) increase enrollment probabilities, as does parents= college attendance. Peer group effects also matter: students are more likely to attend college when greater than 75 percent of their high school class is enrolled in college preparatory courses. Alternatively, having three or more siblings has a consistently negative effect on the probability of enrollment. Finally, the high school region variables do appear to capture broad regional variations in institutional access. Students from high schools in the Northeast are significantly more likely to attend private four-year colleges, while students in the West are more likely to enroll in public two-year colleges. The coefficients on these control variables are quite robust to a wide variety of different specifications of the immigrant variables.

\section{v. Conclusion}

This paper examines the postsecondary enrollment decisions of immigrant students, expanding on previous work by explicitly 
considering their choices among institution types and by examining differences across generations and racial/ethnic categories. We find a significant Aimmigrant effect@ particularly in the first generation. First-generation immigrants are more likely than native-born students to enroll in a postsecondary institution in their first year after high school. Most of the higher enrollment probability in this group occurs at the public institutions, both community colleges and four-year colleges and universities. However, there is also an increase in the probability of choosing a private vocational school. This effect dampens with assimilation: second-generation immigrants are more likely than native-born students to enroll but not as likely as their first-generation counterparts. Additionally, the only institutional alternative that sees a continued immigrant effect into the second generation is the community college option.

These effects vary across immigrant groups of different racial/ethnic categories. Particularly for Asian immigrants, public schools (both two- and four-year institutions) play an important access role to higher education. Asian immigrants are significantly more likely than their native counterparts to enroll in these institutions. Community colleges especially continue to play an important role in the postsecondary education of successive generations of Asian immigrants. In contrast, 
first-generation black immigrants have a significantly higher probability of enrolling in the private vocational schools. And, surprisingly, second-generation Hispanic immigrants are more likely to enroll in traditional four-year colleges and universities, both public and private. No other immigrant group exhibits this effect, and among natives, a similar effect is found only for blacks. Second-generation Hispanic immigrants (in contrast to their Asian counterparts) may be benefitting from affirmative action efforts more focused on blacks and Hispanics.

These results have important implications for higher education policy and raise a number of questions that would benefit from further research. If affirmative action is the dominant explanation for the higher enrollment probabilities at four-year institutions for native blacks and second-generation Hispanics (a hypothesis that merits further investigation), this has important implications for the wave of anti-affirmative action measures spreading throughout the country (e.g. Proposition 209 in California). Additionally, if public colleges, particularly community colleges, are primary access points to higher education for immigrants, policy-makers should be aware of the importance of these institutions in providing what this population needs to become productive members of the labor force. Community colleges especially have the flexibility to respond to the needs of communities with rapidly growing 
immigrant populations. A logical direction for further research is to explore how immigrants progress through the higher education system. Are they likely to transfer from two-year to four-year colleges and universities? As the next waves of the NELS survey become available, we plan to follow these students to determine how their postsecondary enrollment choices affected their eventual educational achievements and labor market contributions. 


\section{Appendix A}

\section{Means and Descriptions of Variables Used in Estimations}

(all variables except those marked ${ }^{*}$ are $0-1$ categorical variables)

$$
\mathrm{N}=10,465
$$

\section{Variable}

Mean

Immigration Status (from Parent questionnaire)

First Generation Immigrant -

Student and at least one parent born outside the U.S.

Second Generation Immigrant -

At least one parent born outside U.S.; student native-born

Race (from student questionnaire)

Asian/Pacific Islander

Hispanic

Black

White, non-Hispanic

\section{Immigrant status - Race interactions}
Asian/Pacific Islander * 1st generation
0.0150
Hispanic $* 1$ st generation
0.0146
Black * 1st generation
0.0032
White (non-Hispanic) * 1st generation
0.0065
Asian/Pacific Islander * 2nd generation
0.0116
Hispanic $* 2$ nd generation
0.0395
Black * 2nd generation
0.0058
White (non-Hispanic) $*$ 2nd generation
0.0344

Female

0.4982

Reading score quintile* (where 1=lowest and 5=highest)

on NELS-administered reading test

Math score quintile* (where 1=lowest and 5=highest) 
Variable

$\underline{\text { Mean }}$

\section{Socioeconomic Status Variables}

Income (in hundreds) - measured as mean income

445.0291 parental-reported income category (7 categories)"

Father in professional occupation - defined by authors based on

reported occupation category (includes office workeres, managers, teachers and other professionals)

Mother in professional occupation (see above)

Father not high school graduate -

higest educational attainment reported less than high school

0.1374

Mother not high school graduate (see above)

0.1289

Father high school graduate, but no postsecondary education

0.2798

Mother high school graduate, but no postsecondary education

0.3344

Father college graduate - obtained bachelor degree or higher

Mother college graduate (see above)

0.2218

No siblings - student had no siblings

0.0625

Three or more siblings - student family had at least 4 children

0.3401

\section{High School characteristics}

High school region - Northeast

0.1869

High school region - South

0.3576

High school region - West

0.1862

High school private (includes religious and non-religious)

0.0918

Less than $25 \%$ of student high school class enrolled in college

0.1513 prepatory program

More than $75 \%$ of student high school class enrolled in college 0.1386 prepatory program 


\section{Table 1}

\section{Percentage Choosing Each Enrollment Alternative by Immigration Status and Ethnicity}

\begin{tabular}{|c|c|c|c|c|c|}
\hline & \multicolumn{5}{|c|}{ Enrollment Choice } \\
\hline & $\begin{array}{c}\text { Non- } \\
\text { Enrollme } \\
\underline{n t}\end{array}$ & $\begin{array}{l}\text { Private } \\
\leq 4 \text {-year } \\
\end{array}$ & $\begin{aligned} & \text { Public } \\
& \leq 4 \text {-year } \\
&\end{aligned}$ & $\begin{array}{c}\text { Private } \\
\underline{4-\text { year }}\end{array}$ & $\begin{array}{l}\text { Public } \\
\text { 4-year }\end{array}$ \\
\hline All students & 40.90 & 2.9 & 18.2 & 12.9 & 25.2 \\
\hline Native-born & 41.44 & 2.93 & 17.49 & 12.94 & 25.20 \\
\hline Generation One & 31.36 & 3.25 & 21.89 & 12.15 & 31.36 \\
\hline Generation Two & 35.66 & 2.22 & 20.21 & 15.78 & 26.13 \\
\hline \multicolumn{6}{|l|}{ Native-born: } \\
\hline Asian & 33.61 & 4.92 & 18.85 & 13.93 & 28.69 \\
\hline Hispanic & 50.73 & 3.89 & 21.88 & 3.57 & 19.94 \\
\hline Black & 51.02 & 3.42 & 13.12 & 9.43 & 23.01 \\
\hline White & 39.15 & 2.78 & 17.76 & 14.26 & 26.05 \\
\hline \multicolumn{6}{|l|}{ Generation one: } \\
\hline Asian & 21.34 & 2.31 & 23.14 & 13.37 & 39.85 \\
\hline Hispanic & 51.18 & 5.21 & 23.22 & 5.21 & 15.17 \\
\hline Black & 31.03 & 6.90 & 6.90 & 24.14 & 31.03 \\
\hline White & 24.32 & 1.35 & 17.57 & 21.62 & 35.14 \\
\hline \multicolumn{6}{|l|}{ Generation two: } \\
\hline Asian & 16.42 & 1.12 & 15.30 & 27.24 & 39.93 \\
\hline Hispanic & 48.11 & 2.70 & 22.88 & 7.75 & 18.56 \\
\hline Black & 34.69 & 2.04 & 16.33 & 22.45 & 24.49 \\
\hline White & 29.97 & 2.37 & 20.47 & 18.99 & 28.19 \\
\hline
\end{tabular}

Rows may not sum to $100 \%$ due to rounding 
TABLE 2

\section{Coefficients from Multinomial Logit Estimation 1 \\ Dependent Variable: Fall Enrollment Choice}

(standard errors in parentheses)

\begin{tabular}{|c|c|c|c|c|}
\hline \multirow[b]{2}{*}{$\begin{array}{l}\text { Independent } \\
\text { Variables } \\
\end{array}$} & \multicolumn{4}{|c|}{ Postsecondary Enrollment Choices } \\
\hline & $\begin{array}{l}\text { Private } \\
\leq 4 \text {-year } \\
\end{array}$ & $\begin{array}{l}\text { Public } \\
\leq 4 \text {-year }\end{array}$ & $\begin{array}{r}\text { Private } \\
\text { 4-year }\end{array}$ & $\begin{array}{l}\text { Public } \\
\text { 4-year }\end{array}$ \\
\hline Intercept & $\begin{array}{r}-2.4688^{* * *} \\
(0.6788)\end{array}$ & $\begin{array}{r}-1.1532^{* * *} \\
(0.3198)\end{array}$ & $\begin{array}{r}-4.1114^{* * * *} \\
(0.4391)\end{array}$ & $\begin{array}{r}-3.1303^{* * *} \\
(0.3336)\end{array}$ \\
\hline $\begin{array}{l}\text { First generation } \\
\text { Immigrant }\end{array}$ & $\begin{array}{c}0.7579^{* * *} \\
(0.2479)\end{array}$ & $\begin{array}{c}0.3898^{* * *} \\
(0.1504)\end{array}$ & $\begin{array}{r}0.2475 \\
(0.2088)\end{array}$ & $\begin{array}{r}0.4422^{* * *} \\
(0.1593)\end{array}$ \\
\hline $\begin{array}{l}\text { Second generation } \\
\text { Immigrant }\end{array}$ & $\begin{array}{r}0.1120 \\
(0.2111)\end{array}$ & $\begin{array}{c}0.2083^{* * *} \\
(0.0988)\end{array}$ & $\begin{array}{r}0.1881 \\
(0.1258)\end{array}$ & $\begin{array}{r}0.1578 \\
(0.1050)\end{array}$ \\
\hline $\begin{array}{l}\text { Asian/Pacific } \\
\text { Islander }\end{array}$ & $\begin{array}{r}-0.1636 \\
(0.3732)\end{array}$ & $\begin{array}{r}0.0146 \\
(0.1690)\end{array}$ & $\begin{array}{r}0.2577 \\
(0.2005)\end{array}$ & $\begin{array}{r}0.1677 \\
(0.1698)\end{array}$ \\
\hline Hispanic & $\begin{array}{r}0.0665 \\
(0.2072)\end{array}$ & $\begin{array}{r}0.0657 \\
(0.0971)\end{array}$ & $\begin{array}{r}0.0832 \\
(0.1552)\end{array}$ & $\begin{array}{r}0.1230 \\
(0.1091)\end{array}$ \\
\hline Black & $\begin{array}{r}0.2104 \\
(0.1619)\end{array}$ & $\begin{array}{r}-0.1159 \\
(0.0897)\end{array}$ & $\begin{array}{c}0.4285^{* * *} \\
(0.1142)\end{array}$ & $\begin{array}{l}0.2217^{* *} \\
(0.0862)\end{array}$ \\
\hline Female & $\begin{array}{c}0.3989^{* * *} \\
(0.1084)\end{array}$ & $\begin{array}{c}0.2238^{* * *} \\
(0.0510)\end{array}$ & $\begin{array}{c}0.4535^{* * *} \\
(0.0669)\end{array}$ & $\begin{array}{r}0.3188^{* * *} \\
(0.0520)\end{array}$ \\
\hline Reading score quintile & $\begin{array}{r}-0.1194 \\
(0.1233)\end{array}$ & $\begin{array}{r}-0.0764 \\
(0.0579)\end{array}$ & $\begin{array}{l}0.1781^{* *} \\
(0.0769)\end{array}$ & $\begin{array}{r}0.0655 \\
(0.0588)\end{array}$ \\
\hline Math score quintile & $\begin{array}{c}0.2337^{*} \\
(0.1279)\end{array}$ & $\begin{array}{c}0.3359^{* * *} \\
(0.0608)\end{array}$ & $\begin{array}{c}0.9146^{* * * *} \\
(0.0833)\end{array}$ & $\begin{array}{r}0.9150^{* * * *} \\
(0.0641)\end{array}$ \\
\hline Income (in thousands) & $\begin{array}{l}0.0008^{* *} \\
(0.0004)\end{array}$ & $\begin{array}{c}0.0008^{* * *} \\
(0.0002)\end{array}$ & $\begin{array}{c}0.0014^{* * *} \\
(0.0002)\end{array}$ & $\begin{array}{r}0.0011^{* * * *} \\
(0.0002)\end{array}$ \\
\hline $\begin{array}{l}\text { Mother's occupation } \\
\text { professional }\end{array}$ & $\begin{array}{r}0.0432 \\
(0.1172)\end{array}$ & $\begin{array}{c}0.2096^{* * *} \\
(0.0542)\end{array}$ & $\begin{array}{r}-0.0124 \\
(0.0688)\end{array}$ & $\begin{array}{l}0.1162^{* *} \\
(0.0543)\end{array}$ \\
\hline $\begin{array}{l}\text { Father's occupation } \\
\text { professional }\end{array}$ & $\begin{array}{c}0.2577^{*} \\
(0.1344)\end{array}$ & $\begin{array}{r}0.0893 \\
(0.0662)\end{array}$ & $\begin{array}{r}0.2345^{* * *} \\
(0.0775)\end{array}$ & $\begin{array}{r}0.1918^{* * *} \\
(0.0636)\end{array}$ \\
\hline
\end{tabular}


Table 2 (cont.)

continuation of multinomial logit results

\begin{tabular}{|c|c|c|c|c|}
\hline $\begin{array}{l}\text { Independent } \\
\text { Variables } \\
\end{array}$ & $\begin{array}{l}\text { Private } \\
\leq 4 \text {-year }\end{array}$ & $\begin{array}{l}\text { Public } \\
\leq \text { 4-year }\end{array}$ & $\begin{array}{r}\text { Private } \\
\text { 4-year }\end{array}$ & $\begin{array}{l}\text { Public } \\
\text { 4-year }\end{array}$ \\
\hline $\begin{array}{l}\text { Father not high school } \\
\text { graduate }\end{array}$ & $\begin{array}{r}0.0053 \\
(0.1770)\end{array}$ & $\begin{array}{c}-0.2172^{* *} \\
(0.0887)\end{array}$ & $\begin{array}{l}-0.2659^{*} \\
(0.1566)\end{array}$ & $\begin{array}{r}-0.3285^{* * *} \\
(0.1019)\end{array}$ \\
\hline $\begin{array}{l}\text { Mother not high school } \\
\text { graduate }\end{array}$ & $\begin{array}{r}-0.1009 \\
(0.1798)\end{array}$ & $\begin{array}{r}-0.1305 \\
(0.0925)\end{array}$ & $\begin{array}{r}-0.4552^{* * *} \\
(0.1730)\end{array}$ & $\begin{array}{r}-0.2082^{* *} \\
(0.1032)\end{array}$ \\
\hline $\begin{array}{l}\text { Father high school grad } \\
\text {-no college }\end{array}$ & $\begin{array}{r}0.0896 \\
(0.1404)\end{array}$ & $\begin{array}{r}-0.0410 \\
(0.0666)\end{array}$ & $\begin{array}{r}-0.1408 \\
(0.0970)\end{array}$ & $\begin{array}{l}-0.1243^{*} \\
(0.0689)\end{array}$ \\
\hline $\begin{array}{l}\text { Mother high school grad } \\
\text {-no college }\end{array}$ & $\begin{array}{r}-0.1000 \\
(0.1385)\end{array}$ & $\begin{array}{r}0.0592 \\
(0.0652)\end{array}$ & $\begin{array}{r}-0.0326 \\
(0.0883)\end{array}$ & $\begin{array}{r}0.0159 \\
(0.0666)\end{array}$ \\
\hline $\begin{array}{l}\text { Father college } \\
\text { graduate }\end{array}$ & $\begin{array}{r}0.0496 \\
(0.1821)\end{array}$ & $\begin{array}{c}0.1388^{*} \\
(0.0825)\end{array}$ & $\begin{array}{c}0.4160^{* * *} \\
(0.0945)\end{array}$ & $\begin{array}{l}0.2383^{* * *} \\
(0.0780)\end{array}$ \\
\hline $\begin{array}{l}\text { Mother college } \\
\text { graduate }\end{array}$ & $\begin{array}{r}0.0768 \\
(0.1806)\end{array}$ & $\begin{array}{r}0.0778 \\
(0.0854)\end{array}$ & $\begin{array}{c}0.2758^{* * *} \\
(0.0935)\end{array}$ & $\begin{array}{r}0.2750^{* * *} \\
(0.0793)\end{array}$ \\
\hline No siblings & $\begin{array}{r}-0.2297 \\
(0.2585)\end{array}$ & $\begin{array}{r}-0.0782 \\
(0.1068)\end{array}$ & $\begin{array}{r}0.0912 \\
(0.1252)\end{array}$ & $\begin{array}{r}0.0048 \\
(0.1020)\end{array}$ \\
\hline Three or more siblings & $\begin{array}{c}-0.2429^{* *} \\
(0.1441)\end{array}$ & $\begin{array}{r}-0.2023^{* * *} \\
(0.0548)\end{array}$ & $\begin{array}{r}-0.3104^{* * *} \\
(0.0747)\end{array}$ & $\begin{array}{r}-0.2471^{* * *} \\
(0.0564)\end{array}$ \\
\hline $\begin{array}{l}\text { High school region - } \\
\text { Northeast }\end{array}$ & $\begin{array}{r}0.1962 \\
(0.1466)\end{array}$ & $\begin{array}{r}-0.1322 \\
(0.0851)\end{array}$ & $\begin{array}{c}0.3424^{* * *} \\
(0.0895)\end{array}$ & $\begin{array}{r}-0.0596 \\
(0.0776)\end{array}$ \\
\hline $\begin{array}{l}\text { High school region - } \\
\text { South }\end{array}$ & $\begin{array}{r}-0.2079 \\
(0.1403)\end{array}$ & $\begin{array}{r}0.0520 \\
(0.0655)\end{array}$ & $\begin{array}{r}-0.2324^{* * *} \\
(0.0889)\end{array}$ & $\begin{array}{r}-0.0555 \\
(0.0650)\end{array}$ \\
\hline $\begin{array}{l}\text { High school region - } \\
\text { West }\end{array}$ & $\begin{array}{r}-0.2114 \\
(0.1670)\end{array}$ & $\begin{array}{c}0.1297^{*} \\
(0.0742)\end{array}$ & $\begin{array}{r}-0.3464^{* * *} \\
(0.1056)\end{array}$ & $\begin{array}{r}-0.3068^{* * *} \\
(0.0800)\end{array}$ \\
\hline High school private & $\begin{array}{r}0.1654 \\
(0.2269)\end{array}$ & $\begin{array}{r}-0.0457 \\
(0.1120)\end{array}$ & $\begin{array}{c}0.4537^{* * *} \\
(0.1103)\end{array}$ & $\begin{array}{r}0.0247 \\
(0.1045)\end{array}$ \\
\hline $\begin{array}{l}\text { Less than } 25 \% \text { of hs class } \\
\text { in college-prep }\end{array}$ & $\begin{array}{l}0.2804^{* *} \\
(0.1276)\end{array}$ & $\begin{array}{r}0.1006 \\
(0.0685)\end{array}$ & $\begin{array}{r}0.1228 \\
(0.0951)\end{array}$ & $\begin{array}{r}0.0660 \\
(0.0726)\end{array}$ \\
\hline $\begin{array}{l}\text { More than } 75 \% \text { of hs class } \\
\text { in college prep }\end{array}$ & $\begin{array}{r}-0.2645 \\
(0.2443)\end{array}$ & $\begin{array}{c}0.2864^{* * *} \\
(0.0925)\end{array}$ & $\begin{array}{c}0.2579^{* * *} \\
(0.1001)\end{array}$ & $\begin{array}{r}0.2883^{* * *} \\
(0.0885)\end{array}$ \\
\hline $\mathrm{N}=10,465$ Likelihood Rat & \multicolumn{3}{|c|}{ Chi-square $=7644.58$} & \\
\hline
\end{tabular}

${ }^{* * *}$ significant at $1 \%$ level, ${ }^{* *}$ significant at $5 \%$ level, ${ }^{*}$ significant at $10 \%$ level 
TABLE 3

\section{Changes in Enrollment Choice Probabilities}

with Change in Independent Variables

\begin{tabular}{|c|c|c|c|c|c|}
\hline \multirow[b]{2}{*}{$\begin{array}{l}\text { Independent } \\
\text { Variables } \\
\end{array}$} & \multicolumn{5}{|c|}{$\begin{array}{l}\text { Change in probability of choosing each alternative } \\
\text { (measured in percentage points) }\end{array}$} \\
\hline & $\begin{array}{c}\begin{array}{c}\text { Non- } \\
\text { Enrllment }\end{array} \\
\end{array}$ & $\begin{array}{l}\text { Private } \\
\leq 4 \text {-year } \\
\end{array}$ & $\begin{array}{c}\text { Public } \\
\leq \text { 4-year } \\
\end{array}$ & $\begin{array}{l}\text { Private } \\
\text { 4-year }\end{array}$ & $\begin{array}{l}\text { Public } \\
\text { 4-year }\end{array}$ \\
\hline Immigrant - 1st generation ${ }^{*}$ & -0.0805 & 0.0316 & 0.0256 & -0.0074 & 0.0307 \\
\hline Immigrant - 2nd generation ${ }^{*}$ & -0.0370 & -0.0010 & 0.0244 & 0.0075 & 0.0061 \\
\hline Asian & -0.0202 & -0.0119 & -0.0161 & 0.0261 & 0.0221 \\
\hline Hispanic & -0.0180 & 0.0003 & 0.0013 & 0.0028 & 0.0136 \\
\hline Black $^{*}$ & -0.0268 & 0.0070 & -0.0580 & 0.0486 & 0.0291 \\
\hline Female ${ }^{*}$ & -0.0648 & 0.0103 & 0.0023 & 0.0301 & 0.0220 \\
\hline Reading score quintile ${ }^{*}$ & -0.0090 & -0.0040 & -0.0179 & 0.0201 & 0.0109 \\
\hline Math score quintile* & -0.1703 & -0.0055 & -0.0147 & 0.0643 & 0.1256 \\
\hline Income* & -0.00025 & 0.00001 & 0.00003 & 0.00010 & 0.00011 \\
\hline Mother occup. prof.* & -0.0267 & -0.00263 & 0.0365 & -0.0128 & 0.0056 \\
\hline Father occup. prof." & -0.0334 & 0.0084 & -0.0075 & 0.0156 & 0.0169 \\
\hline Father not hs graduate $^{*}$ & 0.0519 & 0.0101 & -0.0160 & -0.0126 & -0.0335 \\
\hline Mother not hs graduate ${ }^{*}$ & 0.0444 & 0.0023 & 0.0030 & -0.0356 & -0.0142 \\
\hline Father hs grad - no college ${ }^{*}$ & 0.0155 & 0.0082 & 0.0030 & -0.0112 & -0.0155 \\
\hline Mother hs grad - no college & -0.0035 & -0.0062 & 0.0144 & -0.0056 & 0.0009 \\
\hline Father college graduate $^{*}$ & -0.0442 & -0.0057 & -0.0042 & 0.0355 & 0.0187 \\
\hline Mother college graduate & -0.0364 & -0.0027 & -0.0142 & 0.0198 & 0.0335 \\
\hline No siblings & 0.0066 & -0.0108 & -0.0166 & 0.0150 & 0.0058 \\
\hline Three or more siblings ${ }^{*}$ & 0.0 .09 & -0.0044 & -0.0112 & -0.0180 & -0.0174 \\
\hline HS region - Northeast ${ }^{*}$ & -0.0028 & 0.0112 & -0.0408 & 0.0470 & -0.0145 \\
\hline HS region - South ${ }^{*}$ & 0.0109 & -0.0095 & 0.0269 & -0.0242 & -0.0041 \\
\hline HS region - West ${ }^{*}$ & 0.0219 & -0.0076 & 0.0646 & -0.0320 & -0.0469 \\
\hline High school private ${ }^{*}$ & -0.0203 & 0.0056 & -0.0331 & 0.0572 & -0.0095 \\
\hline HS $<25 \%$ college-prep ${ }^{*}$ & -0.0223 & 0.0124 & 0.0074 & 0.0060 & -0.0035 \\
\hline HS $>75 \%$ college-prep ${ }^{*}$ & -0.0494 & -0.0214 & 0.0348 & 0.0108 & 0.0252 \\
\hline
\end{tabular}

Rows may not sum to 0 due to rounding

*variable was significant in maximum likelihood estimation 
TABLE 4

\section{Coefficients from Multinomial Logit Estimation 2 \\ Dependent Variable: Fall Enrollment Choice}

(standard errors in parentheses)

\begin{tabular}{|c|c|c|c|c|}
\hline \multirow[b]{2}{*}{$\begin{array}{l}\text { Independent } \\
\text { Variables } \\
\end{array}$} & \multicolumn{4}{|c|}{ Postsecondary Enrollment Choices } \\
\hline & $\begin{array}{l}\text { Private } \\
\leq \text { 4-year }\end{array}$ & $\begin{array}{l}\text { Public } \\
\leq \text { 4-year } \\
\end{array}$ & $\begin{array}{l}\text { Private } \\
\text { 4-year } \\
\end{array}$ & $\begin{array}{l}\text { Public } \\
\text { 4-year }\end{array}$ \\
\hline Intercept & $\begin{array}{r}-0.9060 \\
(1.8921)\end{array}$ & $\begin{array}{r}0.6499 \\
(1.1013)\end{array}$ & $\begin{array}{r}-2.4116^{* *} \\
(1.1741)\end{array}$ & $\begin{array}{r}-1.1037^{* * * *} \\
(0.9499)\end{array}$ \\
\hline $\begin{array}{l}\text { Asian/Pacific } \\
\text { Islander }\end{array}$ & $\begin{array}{r}0.1151 \\
(0.5236)\end{array}$ & $\begin{array}{r}-0.4001 \\
(0.3202)\end{array}$ & $\begin{array}{r}-0.0511 \\
(0.3505)\end{array}$ & $\begin{array}{r}-0.1380 \\
(0.2887)\end{array}$ \\
\hline Hispanic & $\begin{array}{r}0.2796 \\
(0.2311)\end{array}$ & $\begin{array}{r}0.0302 \\
(0.1228)\end{array}$ & $\begin{array}{r}-0.1324 \\
(0.2369)\end{array}$ & $\begin{array}{r}0.0439 \\
(0.1426)\end{array}$ \\
\hline Black & $\begin{array}{r}0.1420 \\
(0.1804)\end{array}$ & $\begin{array}{r}-0.0952 \\
(0.0923)\end{array}$ & $\begin{array}{r}0.4503^{* * *} \\
(0.1197)\end{array}$ & $\begin{array}{r}0.2387^{* * *} \\
(0.0892)\end{array}$ \\
\hline $\begin{array}{l}\text { First generation } \\
\quad * \text { Asian }\end{array}$ & $\begin{array}{r}0.2869 \\
(0.7297)\end{array}$ & $\begin{array}{l}0.9153^{* *} \\
(0.3873)\end{array}$ & $\begin{array}{r}0.6764 \\
(0.4414)\end{array}$ & $\begin{array}{l}0.8456^{* *} \\
(0.3619)\end{array}$ \\
\hline $\begin{array}{l}\text { First generation } \\
\quad \text { *Hispanic }\end{array}$ & $\begin{array}{r}0.3806 \\
(0.3788)\end{array}$ & $\begin{array}{c}0.4080^{*} \\
(0.2155)\end{array}$ & $\begin{array}{r}0.4361 \\
(0.4443)\end{array}$ & $\begin{array}{r}0.4303 \\
(0.2645)\end{array}$ \\
\hline $\begin{array}{l}\text { First generation } \\
\quad \text { *Black }\end{array}$ & $\begin{array}{l}1.4878^{* * * *} \\
(0.4328)\end{array}$ & $\begin{array}{r}-0.0233 \\
(0.7338)\end{array}$ & $\begin{array}{r}0.4892 \\
(0.5503)\end{array}$ & $\begin{array}{r}0.4514 \\
(0.4810)\end{array}$ \\
\hline $\begin{array}{l}\text { First generation } \\
\quad * \text { White (non-Hispanic) }\end{array}$ & $\begin{array}{r}0.0974 \\
(0.9454)\end{array}$ & $\begin{array}{r}0.3097 \\
(0.3819)\end{array}$ & $\begin{array}{r}-0.0133 \\
(0.4806)\end{array}$ & $\begin{array}{r}0.4018 \\
(0.3853)\end{array}$ \\
\hline $\begin{array}{l}\text { Second generation } \\
\text { *Asian }\end{array}$ & $\begin{array}{r}0.0936 \\
(0.8860)\end{array}$ & $\begin{array}{c}0.8327^{*} \\
(0.4278)\end{array}$ & $\begin{array}{r}0.6455 \\
(0.4659)\end{array}$ & $\begin{array}{r}0.6319 \\
(0.4058)\end{array}$ \\
\hline $\begin{array}{l}\text { Second generation } \\
\text { *Hispanic }\end{array}$ & $\begin{array}{l}-0.2603 \\
(0.3770)\end{array}$ & $\begin{array}{c}0.2850^{*} \\
(0.1661)\end{array}$ & $\begin{array}{c}0.5868^{*} \\
(0.3014)\end{array}$ & $\begin{array}{r}0.3534^{* *} \\
(0.1966\end{array}$ \\
\hline $\begin{array}{l}\text { Second generation } \\
\quad * \text { Black }\end{array}$ & $\begin{array}{r}-0.4637 \\
(0.8965)\end{array}$ & $\begin{array}{r}-0.0823 \\
(0.3802)\end{array}$ & $\begin{array}{r}-0.3042 \\
(0.4042)\end{array}$ & $\begin{array}{r}-0.2062 \\
(0.3508)\end{array}$ \\
\hline $\begin{array}{l}\text { Second generation } \\
\text { *White (non-Hispanic) }\end{array}$ & $\begin{array}{r}0.3303 \\
(0.2539)\end{array}$ & $\begin{array}{r}0.1694 \\
(0.1413)\end{array}$ & $\begin{array}{r}0.1121 \\
(0.1672)\end{array}$ & $\begin{array}{r}0.0718 \\
(0.1462)\end{array}$ \\
\hline $\mathrm{N}=10,465$ Likelihood Rat & 580 Chi-sq & $=7625.59$ & & \\
\hline
\end{tabular}

${ }^{* * * *}$ significant at $1 \%$ level, ${ }^{* *}$ significant at $5 \%$ level, ${ }^{*}$ significant at $10 \%$ level

Note: Coefficients for control variables are essentially the same as in Estimation 1; therefore, they are not reported here in the interests of space. They are available from the authors. 
TABLE 5

Changes in Enrollment Choice Probabilities

with Change in Independent Variables for Race and Immigration Status

\begin{tabular}{|c|c|c|c|c|c|}
\hline \multirow[b]{2}{*}{$\begin{array}{l}\text { Independent } \\
\text { Variables } \\
\end{array}$} & \multicolumn{5}{|c|}{$\begin{array}{l}\text { Change in probability of choosing each alternative } \\
\text { (measured in percentage points) }\end{array}$} \\
\hline & $\begin{array}{c}\text { Non- } \\
\text { Enrllment }\end{array}$ & $\begin{array}{l}\text { Private } \\
\leq 4 \text {-year }\end{array}$ & $\begin{array}{l}\text { Public } \\
\leq \text { 4-year }\end{array}$ & $\begin{array}{r}\text { Private } \\
\text { 4-year }\end{array}$ & $\begin{array}{l}\text { Public } \\
4 \text {-year }\end{array}$ \\
\hline \multicolumn{6}{|l|}{ Race } \\
\hline Asian & 0.0132 & 0.0204 & -0.0739 & 0.0218 & 0.0184 \\
\hline Hispanic & -0.0017 & 0.0162 & 0.0014 & -0.0219 & 0.0060 \\
\hline Black $^{*}$ & -0.0081 & 0.0004 & -0.0817 & 0.0524 & 0.0370 \\
\hline \multicolumn{6}{|l|}{$\begin{array}{l}\text { First generation } \\
\text { interacted with: }\end{array}$} \\
\hline Asian* & -0.0350 & -0.0229 & 0.0527 & -0.0155 & 0.0206 \\
\hline Hispanic $^{*}$ & -0.0209 & -0.0009 & 0.0043 & 0.0059 & 0.0117 \\
\hline Black $^{*}$ & -0.0205 & 0.1149 & -0.1314 & 0.0153 & 0.0217 \\
\hline White - non-Hispanic & -0.0152 & -0.0093 & 0.0142 & -0.0367 & 0.0470 \\
\hline \multicolumn{6}{|l|}{$\begin{array}{l}\text { Second generation } \\
\text { interacted with: }\end{array}$} \\
\hline Asian ${ }^{*}$ & -0.0311 & -0.0254 & 0.0716 & -0.0032 & -0.0120 \\
\hline Hispanic $^{*}$ & -0.0175 & -0.0260 & -0.0130 & 0.0446 & 0.0170 \\
\hline Black & 0.0116 & -0.0148 & 0.0347 & -0.0187 & -0.0128 \\
\hline White - non-Hispanic & -0.0077 & 0.0128 & 0.0162 & -0.0024 & -0.0190 \\
\hline
\end{tabular}

Rows may not sum to 0 due to rounding

* variable was significant in maximum likelihood estimation

Note: Values for changes in choice probabilities with changes in the control variables are essentially the same as in Table 4 and are not reported here in the interests of saving space. They are available from the authors. 


\section{REFERENCES}

Astin, A. (1982). Minorities in Higher Education. San Francisco: Jossey-Bass.

Becker, G. (1981). A Treatise on the Family. Cambridge: Harvard University Press.

Borjas, G. (1985). "Assimilation, Changes in Cohort Quality, and the Earnings of Immigrants," Journal of Labor Economics, 3(4), 463-489.

Borjas, G. and Tienda, M. (1989). "The Employment and Wages of Legalized Immigrants," International Migration Review, 27 (4), $712-747$.

Duran, B. and Weffer, R. (1992). "Immigrants' Aspirations, High School Process, and Academic Outcomes," American Educational Research Journal, 29(1), 163-181.

Funkhauser, E. and Trejo, S. (1995). "The Labor Market Skills of Recent Male Immigrants: Evidence from the Current Population Survey," Industrial and Labor Relations Review, 48(4), $792-811$.

Ganderton, P. and Santos, R. (1995). "Hispanic College Attendance and Completion: Evidence from the High School and Beyond Surveys," Economics of Education Review, 14(1), 35-46.

Kao, G. and Tienda, M. (1995). "Optimism and Achievement: The Educational Performance of Immigrant Youth," Social Science Quarterly, $76(1), 1-19$.

Liao, T.F. (1993). Anterpreting Probability Models: Logit, Probit and Other Generalized Linear Models, @Sage University Paper series on Quantitative Applications in the Social Sciences, 07-101. Thousand Oaks, CA: Sage.

Maddala, G.S. (1983). Limited-Dependent and Qualitative Variables in Econometrics. Cambridge: Cambridge University Press.

Manski, C. and Wise, D. (1983). College Choice in America. Cambridge, MA: Harvard University Press.

McDonnell, L. and Hill, P. (1993). Newcomers in American Schools: Meeting the Educational Needs of Immigrant Youth. Santa Monica, CA: RAND. 
Ordovensky, J.F. (1995). "Effects of Institutional Attributes on Enrollment Choice: Implications for Postsecondary Vocational Education," Economics of Education Review, 14(4), 335-350.

Radner, R. and Miller, L. (1975). Demand and Supply in U.S. Higher Education. New York: McGraw-Hill.

Rouse, C.E. (1994). "What to do after High School: The Two-year versus Four-year Enrollment Decision," in R. Ehrenberg, ed. Choices and Consequences: Contemporary Policy Issues in Education. Ithaca NY: ILR Press.

Rumbaut, R. (1995). Qhe New Californians: Comparative Research Findings on the Educational Progress of Immigrant Children@ in Rumbaut, R. and W. Cornelius, eds. Californias Immigrant Children. Center for U.S.-Mexican Studies, UC-San Diego.

Schoeni, R., McCarthy, K. and Vernez, G. (1996). The Mixed Economic Progress of Immigrants. RAND.

Stewart, J. and Hyclak, T. (1984). "An Analysis of the Earnings Profiles of Immigrants," Review of Economics and Statistics, $66(2), 292-296$.

U.S. Department of Education, National Center for Education Statistics. (1996). National Education Longitudinal Study (NELS:88/94) Methodology Report, NCES 96-174.

Vernez, G. and Abrahamse, A. (1996). How Immigrants Fare in U.S. Education. Santa Monica, CA: RAND.

Venti, S. and Wise, D. (1983). Individual Attributes and Self-Selection of Higher Education. Journal of Public Economics. $21,1-32$. 